\title{
Natural durability of subfossil oak: wood chemical composition changes through the ages
}

https://doi.org/10.1515/hf-2018-0309

Received December 31, 2018; accepted June 27, 2019; previously published online August 14, 2019

\begin{abstract}
In recent years, subfossil oak has become increasingly popular, particularly in the manufacture of small wooden products. Due to the long period of its underground preservation, detailed knowledge of its properties is essential to properly use this material. In this study, subfossil oak samples dated to approximately 1000, 2000 and 3000 years BP and recent oak samples were chemically analyzed to determine the contents of extractives, the main wood components, and inorganic elements. The results were then evaluated in light of their natural durability. The mass loss of subfossil oak was 2-3 times lower than that of the recent sample, but the age of the subfossil oak itself had no influence on its durability. The long-term leaching process of water-soluble ellagitannins, together with their hydrolysis and bonding in ferric tannate complexes, were responsible for the decreased durability. The oldest subfossil oak had the lowest amount of phenolic compounds and the highest content of inorganic elements. Optical emission spectrometry proved an increase in inorganic elements 5-7 times higher than recent oak content, with the highest increase found for calcium and iron. Compared to recent oaks, subfossil oaks manifested decreased content of carbohydrates and
\end{abstract}

\footnotetext{
*Corresponding author: Jan Baar, Department of Wood Science, Mendel University in Brno, Zemědělská 3, 61300 Brno, Czech Republic, e-mail: jan.baar@mendelu.cz

Zuzana Paschová and Peter Rademacher: Department of Wood Science, Mendel University in Brno, Zemědělská 3, 61300 Brno, Czech Republic

Tamás Hofmann: Institute of Chemistry, University of Sopron, Bajcsy-Zsilinszky Street 4, H-9400 Sopron, Hungary Tomáš Kolár̆: Department of Wood Science, Mendel University in Brno, Zemědělská 3, 61300 Brno, Czech Republic; and Global Change Research Institute CAS, Bělidla 986/4a, 60300 Brno, Czech Republic

Gerald Koch: Johann Heinrich von Thünen Institute, Federal Research Institute for Rural Areas, Forestry and Fisheries, Bundesallee 50, 38116 Braunschweig, Germany

Bodo Saake: Chemical Wood Technology, University of Hamburg, Haidkrugsweg 1, 22885 Barsbüttel-Willinghusen, Germany
}

correspondingly increased lignin content. Our results revealed that subfossil oak cannot be considered a suitable material for exterior use under aerobic conditions.

Keywords: ellagitannins, extractives, inorganic elements, subfossil oak, wood-rotting fungi

\section{Introduction}

Among hardwood species native to Europe, oak heartwood demonstrates some of the highest levels of natural durability, along with black locust and sweet chestnut. The most widespread European oak species are sessile oak [Quercus petraea (Matt.) Liebl.] and pedunculate oak (Quercus robur L.), which are both classified as Classes 2 (durable) to 4 (less durable) in terms of durability according to EN 350:2016 in soil-contact situations. Correspondingly, several studies have found a durability classification between very durable (DC1) and moderately durable (DC3) based on mass losses caused by different Basidiomycetes fungi (Ayadi et al. 2001; Aloui et al. 2004; Guilley et al. 2004). Oak wood has traditionally been used for exterior applications with or without soil contact such as in sleepers/railroad ties, vineyard poles, bridge construction, and carpentry products without any chemical preservation. Considering the popularity of the material, it currently appears that the durability of oak heartwood is significantly overrated, as it has even been found to be non-durable at times (Brischke et al. 2010, 2012). A lower service life or durability of wood in contact with the ground is related to the long-term presence of sufficiently high moisture; this facilitates the activity of wood-degrading agents and different wood-decaying microflora, including soft-rot fungi and bacteria. The natural durability of wood can be further reduced by the leaching of extractives (Aloui et al. 2004; Fojutowski et al. 2014) or their detoxification by soil bacteria (Wakeling and Morris 2014).

Numerous chemical analyses have demonstrated that wood durability is positively correlated with the presence of specific extractives, especially phenolic compounds, and a few of them have confirmed it for oak heartwood as well (Hart and Hillis 1972; Aloui et al. 2004; Guilley et al. 2004; Karami et al. 2014). The main extractives in oak 
heartwood are principally from the group of hydrolyzable tannins (Seikel et al. 1971; Mosedale et al. 1998; Prida et al. 2006). These compounds are composed of esters from gallic acid or ellagic acid with a sugar core that is usually glucose, and are readily hydrolyzed by acids or enzymes into monomeric products (Bhat et al. 1998). The eight main ellagitannins (castalagin, vescalagin, grandinin, roburins A-E) are all known to be present in oak wood (Zhang et al. 2015). The most abundant ones, castalagin and vescalagin, together represent $40-70 \%$ of the total ellagitannin content (Masson et al. 1995). The ellagitannins are water soluble (Viriot et al. 1994) and therefore easily leachable in contact with water. Aloui et al. (2004) demonstrated the influence of oak heartwood leaching on its durability, when all trees in the test showed higher mass loss, and most of them dropped to a lower durability class after leaching.

Buried wood fully saturated with water in conditions inappropriate for biological deterioration has often lasted hundreds or even thousands of years, during which it nevertheless continually leached extractives. Several studies have dealt with the chemical structure alteration and related changes in physical and mechanical properties in archaeological or subfossil oak wood (Bednar and Fengel 1974; Čufar et al. 2008; Esteban et al. 2010; Krutul et al. 2010; Kolář et al. 2014; Koch et al. 2018). Chemical analyses predominantly focused on main wood components, ash content, or inorganic elements, whereas, with just a few exceptions (Solár et al. 1987; Krutul et al. 2010; Dedic et al. 2014), the quantitative and especially qualitative changes with respect to organic extractives are missing. The natural durability of oak wood deposited underground for the long term should be significantly lower due to a loss in toxic tannins caused by leaching or by deactivation by soil components. Subfossil oak samples exposed to degradation by Serpula lacrymans showed twice the mass loss compared to recent oak, but still low - 4.9\% (Horský and Reinprecht 1986). Koch et al. (2018) showed higher mass losses for two white-rot fungi (up to 30\%) for ancient oak piles, but their durability was often comparable to the inner part of recent oak trunk used in their study.
During the last few years, the utilization of subfossil oak wood for practical purposes has become increasingly modern across Europe. Subfossil wood is usually used for the production of rather small interior articles (e.g. pipes, knife handles, and watches) or furniture due to its extraordinariness in appearance and age, while article size is limited by cracks and low dimensional stability. In order to gain deeper knowledge of the material's usability, a wide range of properties have to be tested. Until now, most of the studies have dealt with mechanical properties or chemical analysis of the main wood components and/or inorganic compounds. However, details of the chemical composition revealing the natural durability of subfossil oak wood remain unexplored. Therefore, the objective of this study was to analyze the natural durability of buried oak heartwood with different periods of underground deposition. We hypothesized that the chemical structure analysis (main wood components, inorganic compounds, organic extractives) of these subfossil oaks could explain the differences in decay resistance compared to recent oak heartwood.

\section{Materials and methods}

Sample preparation: Three subfossil oak trunks, each from a different deposition period, were obtained from the Bečva River bank [eastern part of the Czech Republic; $217 \mathrm{~m}$ above sea level (ASL)]. By using trunks of the same geological origin, we eliminated any possible effects of different sediments on the final results. The oak trunks, without preserved sapwood, underwent radiocarbon and dendrochronological dating processes (Kolář and Rybníček 2011) and were selected because the time span between the depositions of the trunks was approximately 1000 years (Table 1). All studied subfossil trunks were identified as a European oak, which mainly includes the species of $Q$. robur and $Q$. petraea. These two species are barely distinguishable at a microscopic level, but still it is possible with $78 \%$ probability based on methodology defined by Feuillat et al. (1997). In combination with the location in which they were found, the subfossil trunks used in this study were most likely pedunculate oak (Kolář et al. 2012). Therefore, our results were further compared with randomly selected heartwood of recent pedunculate oak. From each trunk (A, B, C), 20 samples with dimensions of $25 \times 15 \times 50 \mathrm{~mm}$ were extracted separately from the inner (the third close to the pith) and the outer parts (the third close to the periphery) of the trunks. Only samples free of cracks were selected for the decay test, and

Table 1: Selected characteristics of subfossil oak trunks.

\begin{tabular}{|c|c|c|c|c|c|c|c|}
\hline \multicolumn{4}{|l|}{ Trunk } & \multicolumn{2}{|r|}{ Tree ring } & \multicolumn{2}{|l|}{ Trunk dating } \\
\hline Code & Diameter (cm) & Pith & Sapwood & Number & Width (mm) & Radiocarbon $\left({ }^{14} \mathrm{C}\right)$ & Dendrochronology \\
\hline A & 68 & Yes & No & 120 & 2.77 & $1131-804 \mathrm{BC}$ & - \\
\hline B & 74 & Yes & No & 225 & 1.65 & 208 BC-AD 137 & - \\
\hline C & 60 & Yes & No & 118 & 2.58 & - & After 1018 \\
\hline
\end{tabular}


were stabilized under controlled conditions at $20^{\circ} \mathrm{C} \pm 2^{\circ} \mathrm{C}$ and below $65 \% \pm 5 \%$ relative humidity for 8 weeks before the durability test. The remaining parts from the inner and outer zones were collected, chopped, and ground into powder using an MM 400 mixer mill (Retsch $\mathrm{GmbH}$, Haan, Germany; fineness $\sim 5 \mu \mathrm{m}$ ). The powder was used for subsequent chemical analysis.

Wood main components: Around $200 \mathrm{mg}$ of the sample was hydrolyzed in two steps with $\mathrm{H}_{2} \mathrm{SO}_{4}$ to analyze lignin and carbohydrates. The first hydrolysis step was performed with $2 \mathrm{ml}$ of $72 \% \mathrm{H}_{2} \mathrm{SO}_{4}$ at $30^{\circ} \mathrm{C}$ for $1 \mathrm{~h}$. The reaction mixture was then diluted with $56 \mathrm{ml}$ ultrapure water, and post-hydrolysis was performed in an autoclave ( $30 \mathrm{~min}, 120^{\circ} \mathrm{C}$, and $1.2 \mathrm{bar}$ ). The hydrolysis residue was recovered by filtration over a G4 sinter glass frit followed by washing, drying at $105^{\circ} \mathrm{C}$, and gravimetric determination. The residue represents the acid-insoluble lignin analogous to Klason lignin. The filtrate was analyzed by high-performance anion-exchange chromatography (HPEAC) borate analysis regarding the wood sugars. Separation was performed on an anion exchange resin $\mathrm{MCL}^{\circledR} \mathrm{Gel}$ CA08F (Mitsubishi Chemicals, Tokyo, Japan). The column dimension was $5 \times 120 \mathrm{~mm}$ (Omnifit, packed at $60^{\circ} \mathrm{C}$ ). The mobile phase $\left(0.7 \mathrm{ml} \mathrm{min}^{-1}\right)$ consisted of a 0.3-M potassium borate buffer with $\mathrm{pH} 8.6$ (A) and $0.9 \mathrm{M}$ potassium borate buffer with $\mathrm{pH} 9.5$ (B). After the samples were injected, separation started with $90 \%$ (A) and 10\% (B). Over a time interval of $35 \mathrm{~min}$, the percent concentration was linearly decreased to $10 \%$ of A and simultaneously increased to $90 \%$ of B. A post-column derivatization of monosaccharides with Cu-bichinconinate $\left(0.35 \mathrm{ml} \mathrm{min}^{-1}\right)$ was applied for quantification. The reaction was performed at $105^{\circ} \mathrm{C}$ in a 30-m crocheted Teflon coil of $0.3 \mathrm{~mm}$ inner diameter (I.D.). This enabled the subsequent detection of sugars at $560 \mathrm{~nm}$. The data were processed using Chromeleon software (Thermo Fisher Scientific, Waltham, MA, USA).

Sample extraction and total extractive content (TEC): Five grams of oak powder were placed in a 100-ml glass screwing bottle with $60 \mathrm{ml}$ of water/methanol mixture (50/50, V/V); 100\% methanol was used for a comparison of the yields of chemical compounds in individual solvents due to their different solubility. The measurement of each sample was carried out in eight iterations. Ultrasound extraction ran in a VGT-1860 QT water bath (GuangDong GT Ultrasonic Co., Ltd., Shenzhen City, China) at $40^{\circ} \mathrm{C}$ for $15 \mathrm{~min}$; the supernatant portion was subsequently filtered out, and the wood powder was again extracted with $40 \mathrm{ml}$ of new solvent for the next $15 \mathrm{~min}$. The combined filtered extract volume was measured, and $1 \mathrm{ml}$ was retained for the following chemical analysis. The extract was then placed in a 250-ml Erlenmeyer flask and evaporated in a laboratory oven at $80^{\circ} \mathrm{C}$ until it reached a constant mass. The last step was a gravimetric analysis of the water/methanol soluble extractive content; this was expressed as a percentage of the dry mass.

Phenolic compound content (PCC): The content of phenolic compounds was determined using the Folin-Ciocalteu method and expressed as gallic acid equivalents (mg GAE $\mathrm{g}^{-1}$ of extract) in eight iterations. A total of $0.5 \mathrm{ml}$ of Folin-Ciocalteu phenol reagent (SigmaAldrich spol. s.r.o, Praha, Czech Republic) and $1 \mathrm{ml}$ of $20 \% \mathrm{Na}_{2} \mathrm{CO}_{3}$ (p.a., Penta s.r.o., Praha, Czech Republic) solution was added to a test tube containing $0.1 \mathrm{ml}$ of the water/methanol extract. A $10-\mathrm{ml}$ mixture was made by adding demineralized water. The mixture was shaken well and kept at room temperature for $30 \mathrm{~min}$, occasionally agitating the content. A set of standard reference solutions of gallic acid (Sigma Aldrich; 20, 40, 60, 80, and $100 \mu \mathrm{g} \mathrm{ml}^{-1}$ ) were analyzed in the same manner as the measured samples. Absorbance rates for the test samples as well as the reference solutions were measured against the blank sample at $700 \mathrm{~nm}$ with an ultraviolet (UV)/visible spectrophotometer (Shanghai Metash Instruments Co., Ltd., Shanghai, China).

High-performance liquid chromatography-diode array detection (HPLC-DAD): The selected phenolic compounds in the extracts were analyzed using a 1260 Infinity modular chromatographic system (Agilent Technologies, Inc., Santa Clara, CA, USA) in two iterations. Chromatographic separation was carried out on an Eclipse Plus C18 separation column, $150 \mathrm{~mm} \times 3.0 \mathrm{~mm}$ I.D., $3.5 \mu \mathrm{m}$ (Agilent Technologies, Inc., Santa Clara, CA, USA). The mobile phase for the gradient elution consisted of (A) HPLC gradient-grade methanol (Fisher Scientific, s.r.o., Pardubice, Czech Republic) and (B) 1\% phosphoric acid in demineralized water (p.a., Penta s.r.o., Praha, Czech Republic). Gradient elution chromatography was performed starting with $100 \%$ of B and $0 \%$ of A. Over a time interval of $20 \mathrm{~min}$, the concentration percentages were linearly decreased to $90 \%$ of $B$ and increased to $10 \%$ of A to determine levels of gallic acid, vescalagin, and castalagin. To determine the elution of ellagic acid, the process started with $100 \%$ of $\mathrm{B}$ and $0 \%$ of $\mathrm{A}$, and over a time interval of $20 \mathrm{~min}$, the A concentration percentage was linearly decreased to $10 \%$ of $B$ and increased to $90 \%$ of A. The flow rate of the mobile phase was $0.6 \mathrm{ml} \mathrm{min}-1$, and the column temperature was set to $30^{\circ} \mathrm{C}$. The injection volume of the samples was $1 \mu \mathrm{l}$. The wavelength of $280 \mathrm{~nm}$ was monitored using a DAD detector. Standard reference solutions of gallic acid, castalagin, vescalagin, and ellagic acid (Sigma-Aldrich spol. s.r.o, Praha, Czech Republic) were analyzed using the same method to quantify the compounds in the extracts.

Inorganic elements: We determined the composition of inorganic elements using inductively coupled plasma-optical emission spectrometry (ICP-OES). A total of $0.1 \mathrm{~g}$ of wood powder was poured into Teflon bombs followed by $2.5 \mathrm{ml}$ concentrated $\mathrm{HNO}_{3}$ (p.a.). The samples were heated in an MLS Microwave START device for $30 \mathrm{~min}$ on a setting of maximum $200^{\circ} \mathrm{C}$. After this, the solution was diluted with demineralized water up to $15 \mathrm{ml}$ and measured in a Thermo iCAP 6300 Duo (Thermo Fisher Scientific, Waltham, MA, USA) simultaneous ICP-OES device for up to approximately $30 \mathrm{nrs}$ of elements.

Cellular UV microspectrophotometry (UMSP): We used scanning UMSP according to Koch and Kleist (2001) to investigate the topochemical distribution and alteration of lignin and deposited phenolic extractives on the subcellular level. For the topochemical analyses, small samples of wood $(1 \times 1 \times 5 \mathrm{~mm})$ were representatively selected from the outer parts of subfossil oaks and the reference oak. These blocks were directly embedded in Spurr's epoxy resin (Spurr 1969) under mild vacuum conditions, with several cycles of evacuation and ventilation as described by Kleist and Schmitt (1999) to avoid chemical changes of the lignin and extractives caused by reactions with solvents. Sections of a nominal thickness of $1 \mu \mathrm{m}$ were prepared with a diamond knife, transferred to quartz microscope slides, and embedded in glycerin. A Zeiss UMSP 80 microspectrophotometer was equipped with a scanning stage, making it possible to examine the image profiles at constant wavelengths by using the APAMOS (C. Zeiss, Oberkochen, Germany) scanning program. The scanning program digitizes rectangular fields with a local geometrical resolution of $0.25 \times 0.25 \mu \mathrm{m}$ and offers a photometrical resolution of 4096 
grayscale levels, which are then converted into 14 basic colors to visualize the absorbance intensities. The scans can be depicted as two-dimensional or three-dimensional image profiles including a statistical evaluation (as a histogram) of the UV absorbance. The present study examined lignin and other phenolic extractives deposited in the subfossil wood at a wavelength of $278 \mathrm{~nm}$.

Wood durability against wood-rotting fungi: The natural durability tests were carried out following the EN 113 European standard. Three wood-decay fungi were used to test natural durability, two brown-rot fungi: Poria placenta (Fr.) Cooke and Laetiporus sulphureus (Bull.) Murrill, and one white-rot fungus: Trametes versicolor (L.) Lloyd. The fungi were inoculated in malt agar medium in Kolle flasks under sterile conditions. After completely covering the surface of the medium, the sterilized samples were put into flasks. Wood from beech ( $T$. versicolor and $L$. sulphureus) and pine sapwood (P. placenta) were used as reference samples. Five steam-sterilized samples from each test group were exposed to each fungus for 16 weeks, at a temperature of $22^{\circ} \mathrm{C}$ and $65 \%$ air humidity. The initial mass of test samples was determined by weighing oven-dry mass samples (EN 113). After exposure to the fungi, the surface mycelium on the test samples was removed, the samples were dried at $103^{\circ} \mathrm{C}$, weighed again, and the amount of mass loss was recorded.

\section{Results and discussion}

\section{Analysis of extractives}

The amount of the wood components soluble in water and/or methanol, as well as of phenolic compounds, diminishes with the time the wood was buried in the soil (Figure 1). The oldest subfossil oak A (3000 years old) contained $60 \%$ fewer phenolic compounds in comparison with the most recent subfossil oak C (1000 years old). Usually, fewer extractive compounds were observed

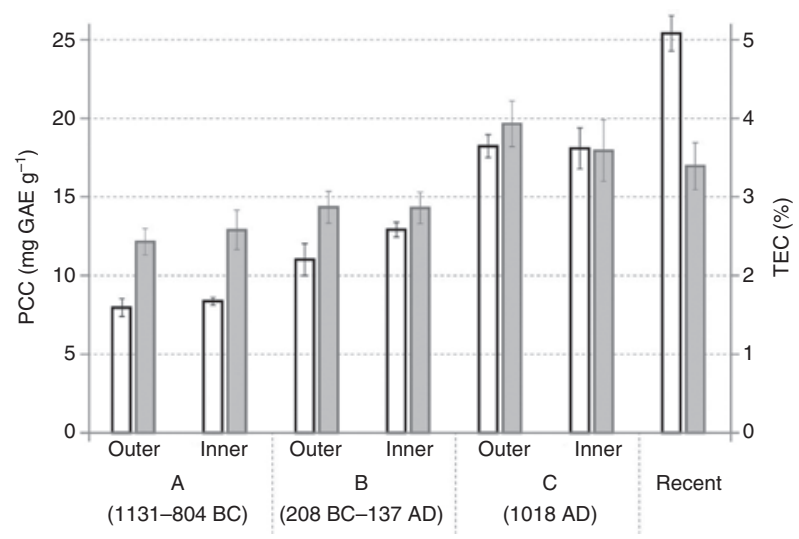

Figure 1: Total extractive content (TEC, gray column) and phenolic compound content (PCC, white column) in the heartwood of subfossil and recent oak. in the outer parts of the trunks in the study; only in the youngest one (C) was this reversed. The content of extractives and phenolic compounds was comparable or slightly higher in oak C compared to recent oak. It is generally known that the composition of extractives varies widely from species to species, and the total amount of extractives in a given species depends on several factors, such as silvicultural and growth conditions, heartwood age, chemical oxidation, genetic disposition, or even the dissolvent capacities of the solvent(s) used (Mosedale et al. 1996; Vivas et al. 1996; Doussot et al. 2002). For instance, Wagenführ (2000) determined the extractive content of Q. robur and Q. petraea to be in a range between $7 \%$ and $19 \%$ depending on the solvent. An amount of extractives ranging from $3.52 \%$ to $12.99 \%$ was obtained by Baar et al. (2017) using the same methodology for 24 different specimens of sessile oak; a similarly wide range was found for phenolic compounds - from 11.08 to $79.75 \mathrm{mg} \mathrm{GAE} \mathrm{g}^{-1}$ dry mass. Moreover, sessile oak is known to be less rich in extractive content than pedunculate oak (Vivas et al. 1996; Prida et al. 2006). It is obvious that the recent oak sample selected as a reference for this study lies at the lower end of the extractive content scale. If we consider the variability of extractive content and compare subfossil oak $\mathrm{C}$ with average values of sessile oak ( $7.3 \%$ and $31.7 \mathrm{mg} \mathrm{GAE} \mathrm{g}^{-1}$ for total extractive and phenolic compounds, respectively) from the above-mentioned experiment, we can assume that the content dropped at least by $50 \%$. On the other hand, during the long-term deposition in wet conditions, not only a leaching process occurred, acid hydrolysis of the main compounds, mainly hemicelluloses, also took place, and indeed contributed to the amount of watersoluble extractives (Solár et al. 1987).

The part of a growing oak trunk richest in phenolic compounds is the peripheral zone of heartwood, and the values gradually decrease toward the pith. Peng et al. (1991) and Viriot et al. (1994) established the same tendency for ellagitannins in sessile oak. Oxidation and polymerization processes would have occurred over time and resulted in the progressive insolubilization of the ellagitannins in oak wood. Moreover, hydrolysis may explain the progressive disappearance of soluble ellagitannins in the older parts of heartwood (Masson et al. 1995). Even so, oak extractives mainly consist of hydrolyzable tannins, which are water soluble. After being buried in soil, these oak wood components dissolve in waterlogged wood, and it is mainly the trunk surface that is exposed to intensive leaching when these components diffuse into surrounding soil due to the concentration gradient. From a longterm view, the gradual migration of dissolved extractives from the inner parts toward the wood surface is probably 
due to same driving force. In combination with chemical changes during a long period of wood storage, this would have resulted in the lower content of these components in subfossil oak samples both throughout the specimen (Solár et al. 1987) and also in its peripheral zones, where the leaching would have been the most intense.

This study identified the presence and amount of gallic and ellagic acid as well as the two most common ellagitannins (vescalagin and castalagin) known in oak wood after employing water-methanol extraction on the heartwood of the analyzed oak trunks. The content of vescalagin and castalagin was 5-15 times higher in recent oak than in the 1000-year-old subfossil oak; as the underground deposition duration of the subfossil oak increased, both ellagitannins dissipated; however, the loss was not major (Table 2). The content of ellagic acid was slightly lower in subfossil oak; only in the outer part of oak C was it comparable to recent oak. Its content decreased as the time underground increased. The highest levels of castalagin were present in recent oak, while ellagic acid was most abundant in the subfossil oak samples (Table 2). Scalbert et al. (1988) found that ellagitannins (hydrolyzable tannins), polyphenolic compounds that comprise the bulk of oak extractives, amount to up to $10 \%$ of the dry weight of European oak heartwood. Of these, monomeric vescalagin and castalagin largely predominate, and together represent $40-70 \%$ of all ellagitannins (Masson et al. 1995). Castalagin and vescalagin are stereoisomers with the same formula. In addition, six other watersoluble ellagic tannins (roburins $\mathrm{A}-\mathrm{E}$ and grandinin) have been documented (Herve Du Penhoat et al. 1991) as dimers of vescalagin or castalagin. Mosedale et al. (1996) determined vescalagin to be the most abundant ellagitannin in outer heartwood; toward the pith, its concentration declines and becomes similar to that of castalagin. Ellagitannins have previously been established as unstable in aqueous solution as well as in woody tissues (Klumpers et al. 1994; Viriot et al. 1994; Charrier et al. 1995), though vescalagin is less stable than castalagin under the same conditions (Lei 2002).

The above-mentioned ellagitannins, rich in hydroxyl groups, are water soluble and hydrolyze into ellagic acid. Acid hydrolysis produces ellagic acid and castalin from castalagin, while the same conditions will hydrolyze vescalagin into ellagic acid and vescalin (Krisper et al. 1992). However, subfossil oaks contain still a high amount of ellagic acid, which is inconsistent with the amount that presumably should be produced by hydrolysis of its ellagitannins.

One complication impeding the extraction of free ellagic acid is its insolubility in water and only partial solubility in many alcohols and other organic solvents (Budavari et al. 1996). Ellagic acid is a weak acid and exhibits a pronounced $\mathrm{pH}$-dependent solubility that increases as $\mathrm{pH}$ increases toward alkaline ranges, with its solubility in acidic or near-neutral solutions being limited (Williams et al. 2016). When using the $100 \%$ methanol as the solvent, the quantity of ellagic acid increased enormously; the amount detected in the case of subfossil oak $\mathrm{C}$ was 20-25 times higher than that of the 50\% methanol solvent (Table 2). The decomposition of ellagitannins by hydrolysis explains the higher volume of ellagic acid in subfossil oak compared to the recent sample. On the other hand, $100 \%$ methanol revealed the lower extraction capacity of water-soluble ellagitannins in recent oak wood. After the hydrolysis of ellagitannins in waterlogged wood, the resulting ellagic acid is not exposed to a diffusion process due to its insolubility in water, and it stayed in the structure of the wood. If we take into account the amount of ellagic acid in subfossil oak C, hydrolysis of ellagitannins is more likely to happen than leaching, and non-water-soluble ellagic acid is further slowly degraded. The leaching

Table 2: Concentrations of ellagitannins $\left(\mu \mathrm{g} \mathrm{g}^{-1}\right)$ in outer $(\mathrm{O})$ and inner (I) specimens of subfossil (A, B, C) and recent (R) oak heartwood; $\mathrm{MeOH} / \mathrm{H}_{2} \mathrm{O}$ : methanol/water 50/50, $\mathrm{MeOH}$ : pure methanol.

\begin{tabular}{|c|c|c|c|c|c|c|c|c|}
\hline \multirow[b]{3}{*}{ CV (\%) } & \multicolumn{2}{|c|}{ Gallic acid } & \multicolumn{2}{|c|}{ Ellagic acid } & \multicolumn{2}{|c|}{ Vescalagin } & \multicolumn{2}{|c|}{ Castalagin } \\
\hline & $\mathrm{MeOH} / \mathrm{H}_{2} \mathrm{O}$ & $\mathrm{MeOH}$ & $\mathrm{MeOH} / \mathrm{H}_{2} \mathrm{O}$ & $\mathrm{MeOH}$ & $\mathrm{MeOH} / \mathrm{H}_{2} \mathrm{O}$ & $\mathrm{MeOH}$ & $\mathrm{MeOH} / \mathrm{H}_{2} \mathrm{O}$ & $\mathrm{MeOH}$ \\
\hline & & 7.0 & & 4.0 & & 7.1 & & 5.8 \\
\hline$A_{0}$ & 33 & 27 & 153 & 2735 & 47 & 46 & 41 & 48 \\
\hline$A_{1}$ & 25 & 34 & 156 & 3770 & 48 & 47 & 44 & 45 \\
\hline $\mathrm{B}_{0}$ & 36 & 60 & 269 & 6752 & 50 & 48 & 50 & 43 \\
\hline$B_{1}$ & 46 & 83 & 364 & 8732 & 49 & 49 & 57 & 45 \\
\hline$C_{0}$ & 117 & 205 & 362 & 8900 & 223 & 217 & 143 & 121 \\
\hline$C_{1}$ & 49 & 73 & 405 & 8558 & 66 & 51 & 118 & 51 \\
\hline$R$ & 235 & 90 & 402 & 1035 & 1097 & 404 & 2122 & 1037 \\
\hline
\end{tabular}


of extractives is supposed to be a slow process on account of the low permeability of oak heartwood, but it is impossible to determine the dependence of the leaching rate on time (over centuries or even millennia); the same is true for the hydrolysis process for extractives.

In addition to the leaching and hydrolysis of ellagitannins, the production of ferric tannate may also contribute to the low content of ellagitannins found in subfossil oak heartwood. Tannins are strong chelators and form a water-soluble ferrous tannate complex with iron, creating dark-colored ferric tannate as they come in contact with oxygen. Ferric tannate complexes are responsible for the dark color of subfossil oak and are insoluble in water, alcohol, and ether, while bases and dilute acids dissolve them (Lewis 1993).

HPLC profiles of main oak heartwood extractives showed that the use of the 50:50 water-methanol solution facilitated the extraction of tannins, while ellagic acid was more readily extracted in pure methanol (Figure 2). The changes among the different subsurface durations of the trunk groups (A, B, C) are apparent, with slight or almost no differences between peripheral and central samples within a given group. The peak doubling in the chromatograms of $\mathrm{A}_{\mathrm{0} 100}, \mathrm{~B}_{1100}$, and $\mathrm{C}_{0100}$ samples in Figure 2 can be explained by the high concentrations of ellagic acid.

\section{Analysis of main wood components}

The content of the main individual components in recent and subfossil oak wood with different subsurface durations is presented in Table 3. The chemical analyses of the wood in this study's investigations showed that the relative share of carbohydrate in subfossil oak is less than that of recent samples (Table 3). Lignin content in the subfossil oak wood was much higher (about 20-30\%) than in the recent wood. The observed increase in lignin is only relative, considering the loss of carbohydrate content due

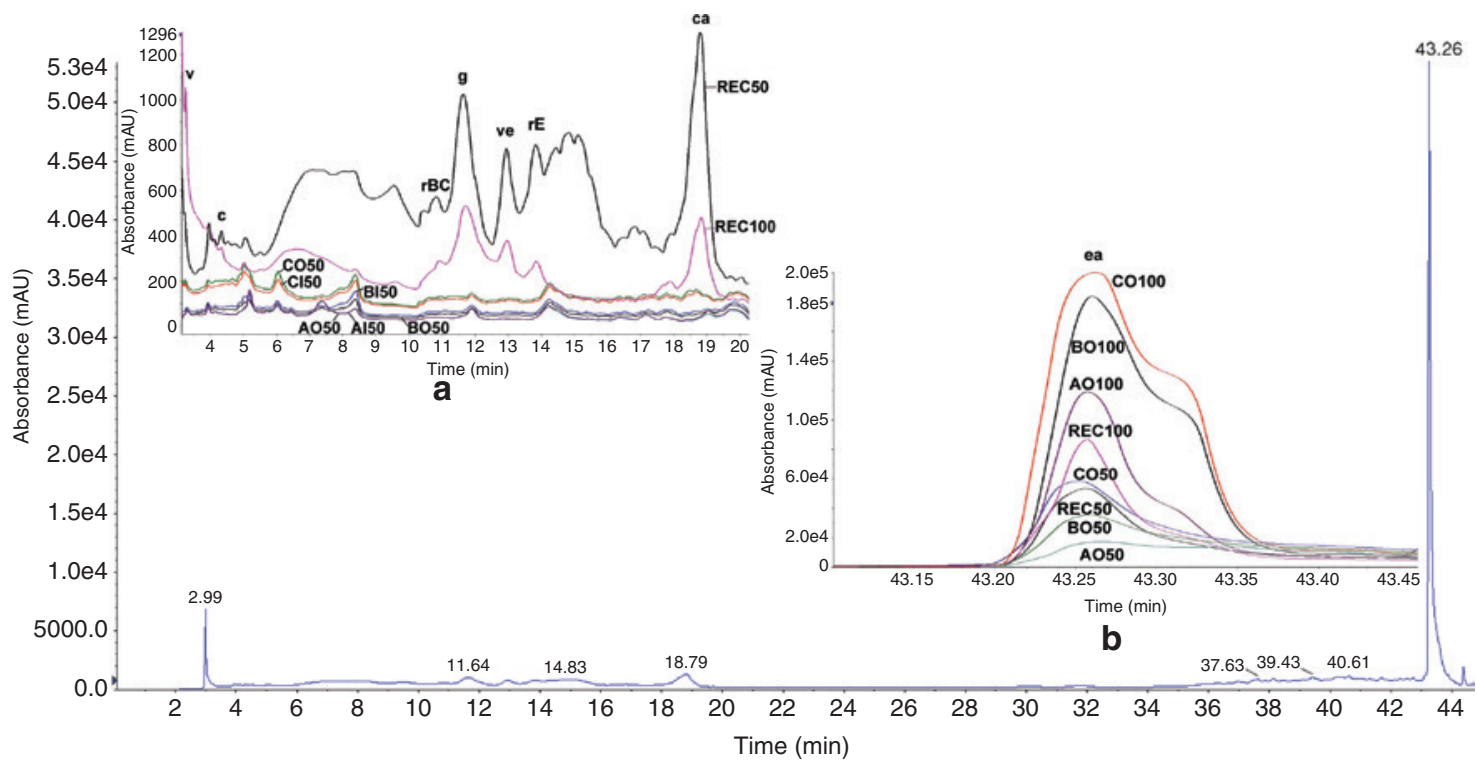

Figure 2: HPLC chromatogram of the main tannins in oak heartwood extracts.

Insets: comparisons of the respective parts of the chromatograms of the given samples. For abbreviations of sample names $\left(A_{0}, A_{1}, B_{0}, B_{1}\right.$, $\left.C_{0}, C_{1}\right)$ refer to Table 2; 50: extracts prepared using a water/methanol solution (50/50); 100: extracts prepared using $100 \%$ methanol; REC: recent sample. c, castalin; ca, castalagin; ea, ellagic acid; g, gallic acid; rBC, roburin B and C; rE, roburin E; v, vescalin; ve, vescalagin.

Table 3: Chemical composition of subfossil (A, B, C) and recent (R) oak heartwood (\% w/w on dry matter).

\begin{tabular}{lrrrrrrr}
\hline Components & A & B & C & R & Solár et al. (1987) & Bednar and Fengel (1974) $^{\text {Kollmann and Fengel (1965) }}$ \\
\hline Lignin & 28.9 & 29.3 & 31.5 & 23.5 & 21.5 & 24.5 & 22.2 \\
Glucose & 50.0 & 48.4 & 44.4 & 55.2 & 46.1 & 37.6 & 40.5 \\
Xylose & 18.7 & 18.8 & 21.2 & 16.7 & 23.9 & 27.7 & 23.3 \\
Other & 2.4 & 3.5 & 2.9 & 4.6 & 2.1 & & 77.0 \\
Carbohydrates & 71.1 & 70.7 & 68.5 & 76.5 & 72.1 & 73.2 \\
\hline
\end{tabular}

Literature data for recent oak heartwood: aglucose is only represented by cellulose; “xylose and other" includes all hemicelluloses. 
to slow hydrolysis processes (Passialis 1997), where the lower resistance of hemicelluloses vis-à-vis cellulose is well known; this is caused by their structural differences. In our study, xylose represents the main constituent of glucuronoxylans, which in turn represent the major group of hemicelluloses found in hardwoods; these typically amount to between $15 \%$ and $30 \%$ of the sample by weight. Glucose represents cellulose, and is also a component of glucomannan, which itself is another group of hemicelluloses present in hardwoods in smaller amounts (2-5\%). Preferential decomposition of xylose containing hemicelluloses occurred in subfossil oak (Solár et al. 1987), which corresponded with our results - the highest xylose content was in the youngest subfossil oak (C). Nevertheless, in the recent oak under analysis, we found a much lower content of xylose (16.7\%), which is considerably lower than the value stated by Solár et al. (1987) - 23.9\%. High variability in the composition of oak wood's main components, as many authors have already shown (e.g. in Bednar and Fengel 1974), and the fact that it is mainly deposition conditions, rather than time alone, that determine the mechanism and rate of wood degradation (Krutul and Kocon 1982), both help to explain why no time-dependent trend in the change in individual components was clearly observed in this study.

\section{Ultraviolet microspectrophotometric analysis (UMSP)}

Next, cellular-scanning UMSP was used to analyze the topochemical distribution and semi-quantitative determination of lignin and phenolic extractives in the tissue of the various specimens of oak heartwood at the cell-wall level. The $\mathrm{S}_{2}$ layers of the recent oak revealed a typical uniform UV absorbance in the range of 0.1-0.15 (Figure $3 R)$. In comparison, the $S_{2}$ layers of subfossil oaks $B$ and $C$ were characterized by locally increased absorbance values (0.15-0.2) in regions adjacent to the compound middle lamella (Figure 3B, C). The relative increase in the lignin content usually caused by hydrolysis and loss of polysaccharides can affect the overall UV-absorbance behavior of the cell wall layers. The cell corners remained unchanged over time, showing the high UV-absorbance values typical of recent oak. However, the UV scanning profiles of the $\mathrm{S}_{2}$ in the tissue of the oldest subfossil oak (Figure 3, upper "A") showed detached layers visible as circular fragments in the cell lumina. The occurrence of these decompositions can basically be described as an impact from bacteria. More specifically, deterioration by slow hydrolysis processes in waterlogged wood is often accompanied by tunneling and erosion from bacteria activity, which seems to be the primary agent responsible for the degradation due to nearanaerobic conditions and which is most pronounced in the polysaccharide-rich $S_{2}$ layer (Blanchette et al. 1990).

The cell wall layers of the vessels were basically characterized by higher UV-absorbance intensities ranging between 0.3 and 0.4 compared to the $\mathrm{S}_{2}$ layers of the fiber cells (Figure 3). No distinct differences of the spectral behavior of the individual vessel elements under study were detectable. In general, the chemical composition of lignin varies among cell types in hardwood. Strongly absorbing guaiacyl lignin predominates in cells involved with water conduction (vessels), while syringyl lignin, which absorbs about 4 times less UV than guaiacyl at $280 \mathrm{~nm}$, predominates in fibers and parenchyma cells (Fergus and Goring 1970; Musha and Goring 1975).

The UV scanning images demonstrate that phenolic extractives, especially in the tissue of the subfossil oak, were deposited in the lumina of the parenchyma cells and locally impregnated in cell walls in the regions of the pit canals (Figure 4). These compounds are characterized by relatively high absorbance, in the range of 0.65-1.0 (overflow), compared to the UV absorbance of the lignified cell wall layers. Corresponding to previous topochemical studies of subfossil oaks (Čufar et al. 2008; Koch et al. 2018), the phenolic extractives detected in this study can presumably be attributed to brenzcatechine compounds caused by mineral staining (iron tannin complexes) in discolored oak wood.

\section{Analysis of inorganic elements}

Subfossil oak trunks go through a process of fossilization, where the types of inorganic substances that replace organic substances depend on the subsurface environment; usually calcification or silicification takes place (Fengel and Wegener 1989; Florian 1990). Whereas most sound wood produces less than $1 \mathrm{wt} \%$ of ash upon combustion, old waterlogged wood sometimes has an ash content of $10 \%$ or more (Hedges 1990), and this content steadily decreases from outside to inside (Kolář et al. 2014; Koch et al. 2018). Tables 4 and 5 show the changes in the composition of inorganic compounds in subfossil oak wood compared to recent oak. It is obvious that the total content of inorganic compounds (including others not stated in Table 4 or 5) is higher in subfossil oak, and amounts to 5-7 times the content of recent oak. Differences between subfossil oak of different subsurface durations were not very substantial, with the exception of iron. The biggest differences between subfossil and recent 

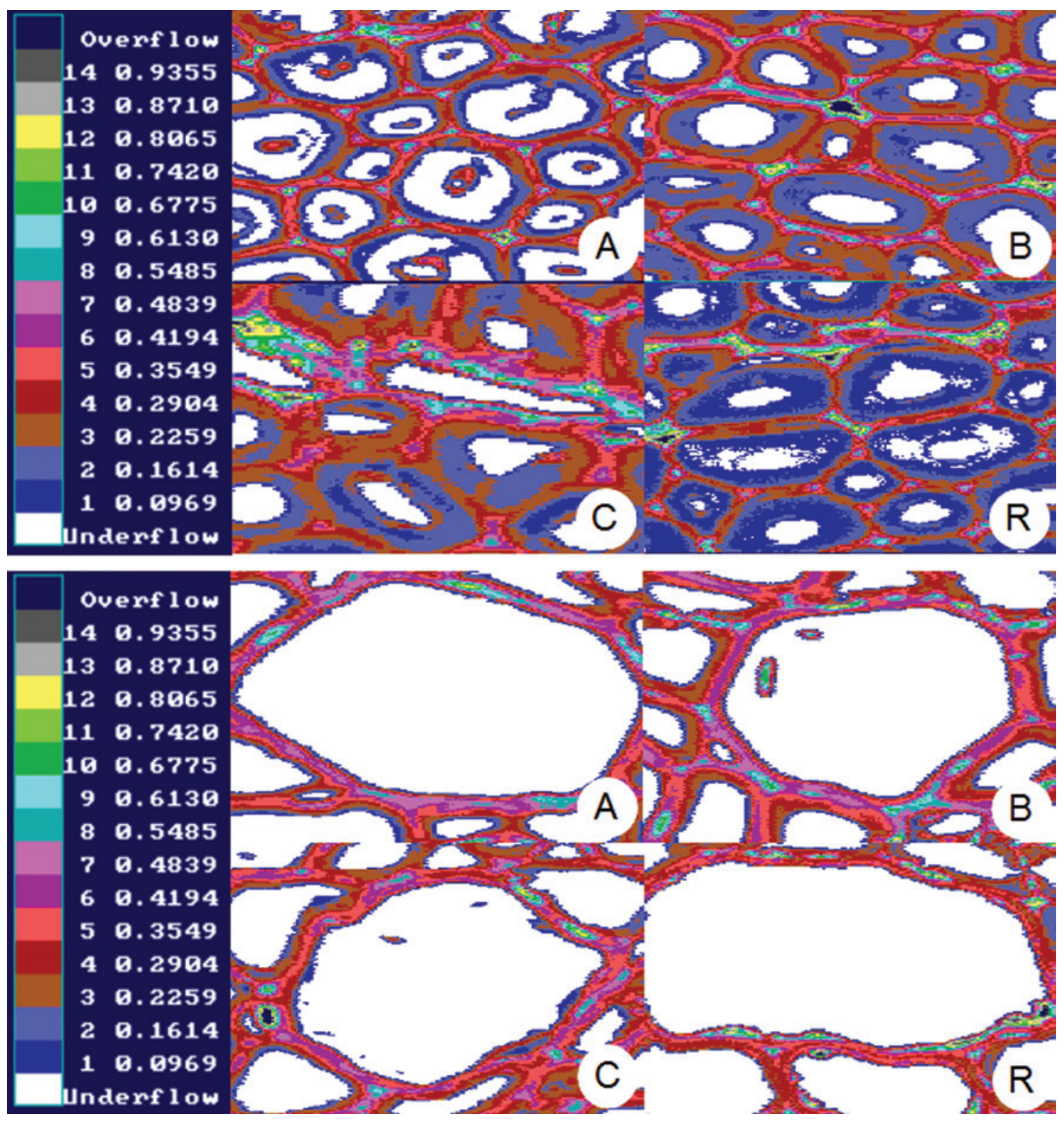

Figure 3: UV-microscope scanning profiles of libriform fibers (upper, field size $48.75 \times 47.75 \mu \mathrm{m}$ ) and latewood vessels and axial parenchyma cells (lower, field size $54.50 \times 53.50 \mu \mathrm{m}$ ) of subfossil oaks (A, B, C) and recent oak (R); the color pixels represent different levels of UV absorbance measured at a wavelength of $278 \mathrm{~nm}$ for topochemical analyses of lignin and phenolic extractives.

oak wood were seen in the levels of calcium, iron, magnesium, and potassium. While the amounts of the first three of these all distinctively increase, the iron content increases even more dramatically - about 1200 times higher in the oldest subfossil oak wood, the concentration of potassium, on the other hand, is much lower in subfossil oak $\left(34 \mu \mathrm{g} \cdot \mathrm{g}^{-1}\right)$ compared to recent oak $\left(612 \mu \mathrm{g} \cdot \mathrm{g}^{-1}\right)$ due to its mobility in water. Similar results were found in 2500-year-old fossilized oak wood (Krutul et al. 2010). Ca, $\mathrm{K}$, and $\mathrm{Mg}$ values also were taken by Welling et al. (2018) in bridge piles dating from earlier time periods $\left(14^{\text {th }}-17^{\text {th }}\right.$ centuries), in which they showed a corresponding pattern for five generations of piles, indicating saturation of the wood by these compounds. As fossilized trunks, where the organic matter has been completely substituted by minerals, indicate, the process of mineral element storage is constantly running, lasting up to millions of years. As such, it is not possible to determine the rate of wood saturation by these compounds on a scale of centuries or even millennia, despite finding significant differences in their amounts in wood from different yet relatively close time periods (from the perspective of the duration of permineralization). Based on our data, it is obvious that subfossil oak has gone through a process of calcification, which 


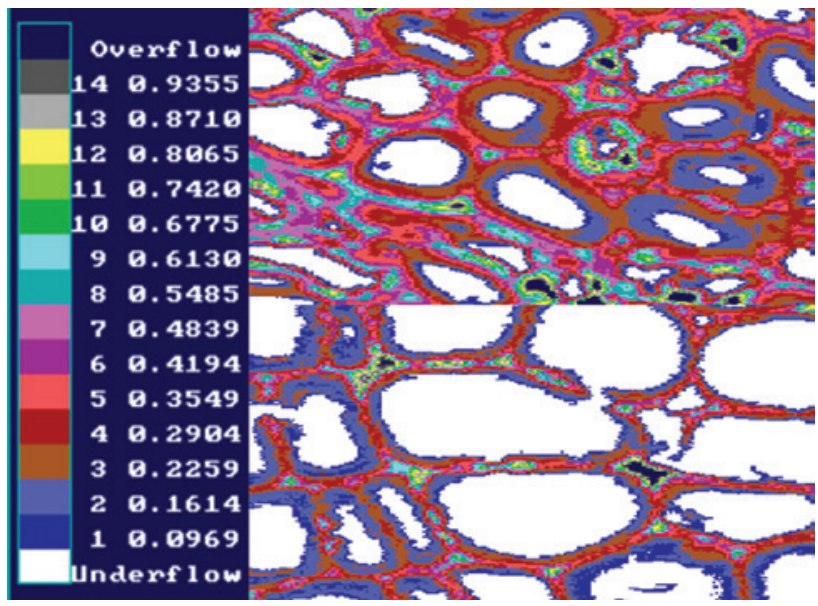

Figure 4: UV-microscope scanning profiles of axial parenchyma tissue in earlywood zones of subfossil oak $A$ (upper) and recent oak (lower); field size $68.50 \times 54.25 \mu \mathrm{m}$; the color pixels represent different levels of UV absorbance measured at a wavelength of $278 \mathrm{~nm}$ for topochemical analyses of lignin and phenolic extractives.

corresponds to the composition of the groundwater and the subsoil at the location of the logs' deposition (Kolár et al. 2014).

Iron is the fourth most abundant element on Earth, and in the form of various combined ores, it constitutes about $5 \%$ of the Earth's crust. The most important ironcontaining minerals are oxides or hydroxides and sulfides (Bernát 1983). The presence of iron in groundwater is a direct result of its natural existence in rock formations as well as soils and precipitation water that infiltrates through these formations and dissolves iron, which is accumulated in aquifers. Especially in the case of oak subfossil heartwood, an enormous increase in iron content is related to a high content of tannins, which are excellent chelators of metal ions. With iron, they form blueblack complexes, which are largely insoluble in water (Mila et al. 1996). At the location where the subfossil trunks used for this study were found, a distinct limonite incrustation could be observed in arenaceous sediments primarily near the groundwater level (Vít et al. 2009). Mańkowski et al. (2013) found no uniform distribution
Table 5: Inorganic biocidal constituent elements in subfossil (A, B, C) and recent $(R)$ oak heartwood.

\begin{tabular}{rrrrr}
\hline & \multicolumn{4}{c}{ Constituent elements $\left(\mu \mathrm{g} \mathrm{g}^{-1}\right)$} \\
\hline B & $\mathrm{Cu}$ & $\mathrm{Zn}$ & $\mathrm{Cr}$ \\
\hline $\mathrm{A}$ & $3.69 \pm 0.03$ & $1.13 \pm 0.02$ & $0.63 \pm 0.004$ & $0.14 \pm 0.03$ \\
$\mathrm{~B}$ & $3.26 \pm 0.05$ & $1.19 \pm 0.02$ & $0.50 \pm 0.006$ & $0.17 \pm 0.02$ \\
$\mathrm{C}$ & $3.67 \pm 0.04$ & $1.60 \pm 0.04$ & $0.21 \pm 0.008$ & $0.14 \pm 0.02$ \\
$\mathrm{R}$ & $3.5 \pm 0.4$ & $1.08 \pm 0.05$ & $0.50 \pm 0.005$ & $0.27 \pm 0.04$ \\
\hline
\end{tabular}

of iron in archaeological oak wood from the $11^{\text {th }}$ century, though there was a distinctively lower content in sapwood compared to the adjacent heartwood zone; this can be explained by the low tannin content in sapwood.

The content of biocidal elements commonly used in wood preservation agents ( $\mathrm{B}, \mathrm{Cu}, \mathrm{Zn}$, and $\mathrm{Cr}$ ) did not show any substantial change after long-term deposition of the logs in soil (Table 5).

\section{Decay test}

The average mass loss in the virulence samples (beech and pine sapwood) reached values higher than the minimal value indicated by EN 113, which proved the fungus' virulence as well as the test's validity. Laetiporus sulphureus is not a test fungus recommended by the standard, but still the mass loss in the virulence beech samples was slightly higher compared to T. versicolor, so fungus virulence was confirmed as well. The decrease in the oak wood's resistance against the three wood-decay fungi after the specimens' long-term deposition in soil was obvious for all the subfossil oaks in the study. The Kruskal-Wallis test indicated that differences in the mass loss between the outer and inner parts of subfossil oak trunks were not significant (Table 6). The same test only showed significant differences in mass loss between recent oak and subfossil oaks $A$ and $B$ when the outer and inner trunk parts were tested separately (Table 6). The same result was achieved when both parts were combined and whole trunks (10 samples

Table 4: Inorganic constituent elements in subfossil (A, B, C) and recent (R) oak heartwood.

Constituent elements $\left(\mu \mathrm{g} \mathrm{g}^{-1}\right)$

\begin{tabular}{|c|c|c|c|c|c|c|c|}
\hline & $\mathrm{Ca}$ & $\mathrm{Fe}$ & $\mathbf{M g}$ & Mn & K & Si & Total \\
\hline A & $3839 \pm 25$ & $2625 \pm 13$ & $256 \pm 0.3$ & $76.1 \pm 0.3$ & $34.0 \pm 0.1$ & $31.7 \pm 0.02$ & 6521 \\
\hline B & $3466 \pm 26$ & $1668 \pm 15$ & $228 \pm 0.9$ & $70.8 \pm 0.2$ & $74.9 \pm 0.3$ & $53.7 \pm 0.07$ & 5214 \\
\hline C & $3878 \pm 22$ & $1078 \pm 5$ & $217 \pm 0.8$ & $72.6 \pm 0.4$ & $61.5 \pm 0.2$ & $56.4 \pm 0.3$ & 5343 \\
\hline $\mathrm{R}$ & $452 \pm 9$ & $3.0 \pm 0.2$ & $4.6 \pm 0.1$ & $27.2 \pm 0.4$ & $612 \pm 7$ & $26.9 \pm 0.3$ & 971 \\
\hline
\end{tabular}


per trunk) were compared. At the same time, no significant differences in mass loss were found between subfossil oak samples from different time periods, even though the youngest one was 2000 years more recent than the oldest one. Their average mass losses were 2- to 3-fold higher than recent oak heartwood, where the average value ranged between $5.0 \%$ and $11.1 \%$ dependent on the fungus species (Table 6).

Although pedunculate oak ( $Q$. robur L.) as well as sessile oak ( $Q$. petraea) were classified as "durable" (class 2) wood species (EN 350-2:1994), previous recent studies have revealed huge variability of its durability, ranging from "very durable" to "not durable" (Ayadi et al. 2001; Guilley et al. 2004; Meyer et al. 2014). These findings, especially from tests with ground contact, led to their reclassification in EN 350:2016. Similarly to our results, Aloui et al. (2004) found a considerable loss of mass for sessile oak (6.2\%) and pedunculate oak (4.1\%) when exposed to T. versicolor. Szczepkowski (2010) found a slightly lower decay rate of oak heartwood when exposed to T. versicolor and $L$. sulphureus $-1.7 \%$ and $7.0 \%$, respectively. Guilley et al. (2004) noted huge variability in mass loss (1-43\%) caused by $T$. versicolor in heartwood samples of sessile oak of different origins. In our study, the greatest mass loss of all tested sets was caused by $L$. sulphureus, which correlates with the fact that it is a common decomposer of tannin-rich heartwood in nature. Fungal oxidases, such as tyrosinase, cause the enzymatic detoxification of phenolic compounds, and they can be found in almost all brownrot fungi decaying heartwood (Lyr 1962).

Hart and Hillis (1972) demonstrated that tannins were responsible for oak heartwood durability, and therefore their content as well as their qualitative variability is important and influences the ultimate natural durability

Table 6: Average mass losses (ML) in \% and variation coefficient of reference species (beech, pine sapwood), subfossil (A, B, C), and recent $(R)$ oak wood exposed to decay fungi ( $\mathrm{O}$ - outer, I - inner).

\begin{tabular}{lrrr}
\hline & Trametes versicolor & Poria placenta & Laetiporus sulphureus \\
\hline $\mathrm{A}_{0}$ & $10.0(13)^{\mathrm{a}}$ & $19.5(27)^{\mathrm{a}}$ & $33.2(14)^{\mathrm{a}}$ \\
$\mathrm{A}_{1}$ & $8.8(16)^{\mathrm{a}}$ & $21.9(11)^{\mathrm{a}}$ & $26.9(19)^{\mathrm{a}}$ \\
$\mathrm{B}_{0}$ & $11.6(12)^{\mathrm{a}}$ & $22.1(18)^{\mathrm{a}}$ & $30.1(9)^{\mathrm{a}}$ \\
$\mathrm{B}_{1}$ & $10.9(20)^{\mathrm{a}}$ & $20.4(15)^{\mathrm{a}}$ & $30.9(16)^{\mathrm{a}}$ \\
$\mathrm{C}_{0}$ & $8.9(20)^{\mathrm{ab}}$ & $18.0(19)^{\mathrm{ab}}$ & $26.1(6)^{\mathrm{ab}}$ \\
$\mathrm{C}_{1}$ & $8.1(31)^{\mathrm{ab}}$ & $17.8(18)^{\mathrm{ab}}$ & $27.9(12)^{\mathrm{ab}}$ \\
$\mathrm{R}$ & $5.0(20)^{\mathrm{b}}$ & $9.9(25)^{\mathrm{b}}$ & $11.1(38)^{\mathrm{b}}$ \\
Beech & $38.8(11)$ & - & $43.3(14)$ \\
Pine & - & $29.3(20)$ & - \\
\hline
\end{tabular}

Mass loss with the same letters are statistically similar $(P<0.05)$ according to the nonparametric Kruskal-Wallis test. of a wood specimen. Tannins act as a defense system against microbial and animal attacks for plants due to their astringent capacity as well as serving as growth inhibitors due to their ability to form strong complexes with microbial enzymes and polysaccharides (Swain and Bate-Smith 1962; Haslam 1996). In some cases, they can also inhibit the growth of microorganisms by denying them iron (Mila et al. 1996). Guilley et al. (2004) correlated higher levels of natural durability of oak heartwood with higher total ellagitannin content, while each of the eight main oak tannins (roburin A, B, C, D, and E, grandinin, vescalagin, castalagin) could equally explain mass losses. Our results reveal that the content of phenolic compounds, which are extractable by a water-methanol mixture, decreases with time of deposition (Figure 1); this is also true of the two most abundant ellagitannins - vescalagin and castalagin (Table 2). A lower amount of fungitoxic phenolic compounds definitely leads to lower durability, which in our samples was 2-3 times lower in subfossil oak than in recent oak wood (in terms of mass loss - see Table 6).

The leaching of tannins is at first glance a presumable reason for the lower durability against wood-rotting fungi in subfossil oak. Several studies have shown a generally higher susceptibility of oak heartwood after leaching, be it artificial or natural, connected with a washout of watersoluble compounds (Aloui et al. 2004; Guilley et al. 2004; Thaler and Humar 2013; Fojutowski et al. 2014). The presence of tylosis in oak vessels could limit water mobility and slow down the process of extractive leaching (Aloui et al. 2004), particularly if we consider extractive migration in old tree logs with large diameters. That means that the leaching of extractives does not have to be the main reason for their significant decrease, especially in the inner part of logs.

Another way extractive loss may occur is gradual detoxification, during which hydrolysis breaks the ellagitannins down into ellagic acid and glucose in the slightly acidic environment of oak heartwood. The heartwood could gradually become more decay-susceptible as the fungistatic compounds are destroyed by enzymatic detoxification, polymerization, or hydrolysis (Hart and Hillis 1972). Ellagic acid, as a product of hydrolysis, is (unlike ellagitannins) non-soluble in water and its leaching from wood is therefore restricted during waterlogging, as the results in Table 2 show. Ellagic acid possesses antimutagenic, antioxidant, anti-inflammatory, and anticancer qualities in bacterial or mammalian systems (Maas et al. 1991), but its effect on wood-rotting fungi is limited due to its small molecular weight. In general, it seems that a minimum molecular weight of $500 \mathrm{~g} \mathrm{~mol}^{-1}$ is needed to inhibit fungal enzyme activity (Williams 1963). In contrast to vescalagin and castalagin $\left(934 \mathrm{~g} \mathrm{~mol}^{-1}\right)$, the molecular 
weights of gallic and ellagic acid are lower than this limit (170 and $302 \mathrm{~g} \mathrm{~mol}^{-1}$, respectively). Generally, the microbial toxicity of natural polyphenols is usually low; to provide effective wood protection, they must accumulate in large amounts, often exceeding $10 \%$ of the heartwood dry weight (Scalbert 1992). Ellagic acid's low toxicity along with its lower content is not sufficient to create conditions that completely prevent fungal growth and enzyme activity.

According to Horský and Reinprecht (1986), the presence of mineral salts (based on $\mathrm{Cu}, \mathrm{Zn}, \mathrm{As}, \mathrm{Sn}$, or B) partly toxic to organisms can positively influence the natural durability of subfossil oak. Wood-rotting fungi require trace amounts of essential heavy metals such as $\mathrm{Cu}, \mathrm{Mn}$, or $\mathrm{Zn}$ for their growth or decomposition activity, but the same metals are often toxic at concentrations only a few times higher than those required. Toxic essential or nonessential heavy metals can inhibit growth, cause morphological and physiological changes, and affect the reproduction of Basidiomycetes (Jellison et al. 1997; Baldrian 2003). The ICP-OES analysis did not prove any significant rise in heavy metal content compared to recent oak wood except iron, which is presumably bonded in non-water-soluble ferric tannate complexes. A thick layer of crystallized mineral substances on the surface of tyloses in the vessels and fibers of subfossil oak has been observed by electron microscopy (Horský and Reinprecht 1986; Krutul et al. 2010), which can hinder fungi spreading from cell to cell or penetrating directly through the cell wall by producing a bore hole. In our study, the lower levels of mass loss of subfossil oaks in comparison with reference beech wood samples can be therefore explained by the slower colonization of samples by fungi together with the process of partial degradation of easily hydrolyzable polysaccharides and the subsequent leaching of degradation products. The effect of phenolic compounds, even if in low amounts, must be considered as well.

The process of fungus degradation of subfossil oak heartwood is influenced by many chemical changes, which can have a negative effect; however, some of them may also positively affect final wood durability. The decrease in tannin content caused partly by leaching, but mainly by slow hydrolysis and tannins' transformation into rather ineffective ellagic acid had the greatest impact on reduced resistance against fungi. The remaining free hydrolyzable tannins were in insufficient concentration necessary to inhibit fungus, or their hydroxyl groups - essential for reactions with microbial enzymes or polysaccharides - were mostly blocked by iron ions. Increased amounts of individual inorganic compounds may even support fungus growth and decay activity by facilitating access to required essential trace elements.
The above-mentioned loss of easily available polysaccharides could be compensated for by the partial depolymerization of the remaining polysaccharides, which became more accessible for enzymatic degradation.

\section{Conclusion}

The mass losses caused by wood-rotting fungi showed that subfossil oak heartwood is more susceptible to decay than samples of heartwood from recent oak. This decrease is mainly related to chemical changes that occurred during the long period of being buried below ground. This study has demonstrated a gradual decrease in the total content of extractive and of phenolic compounds in subfossil oaks that corresponds with the duration of the period underground. The study also found a considerably increased amount of ellagic acid, which is a degradation product of ellagitannin hydrolysis, in all subfossil oaks. The longterm leaching process of water-soluble ellagitannins, together with their hydrolysis and bonding in non-watersoluble ferric tannate complexes, is responsible for the decrease in fungitoxic substances. Our study also demonstrated a decrease in carbohydrate content and an apparent related increase in lignin in subfossil oaks, which was confirmed by UMSP.

In addition, the study also revealed an increase in inorganic elements, particularly for iron, as well as calcium to a significant extent. In light of the chemical changes in oak and their effects on durability, it is obvious that subfossil oak is not a material suitable for exterior use.

Author contributions: All the authors have accepted responsibility for the entire content of this submitted manuscript and approved submission.

Research funding: The paper was supported by the European Social Fund and the state budget of the Czech Republic, project "The Establishment of an International Research Team for the Development of New Wood-based Materials”, reg. no. CZ.1.07/2.3.00/20.0269 (funder Id: http://dx.doi.org/10.13039/501100004895) and the Czech Science Foundation project no. GA18-11004S (funder Id: http://dx.doi.org/10.13039/501100001824), Extension of the Czech Millennia-long Oak Tree-ring Width Chronology; and the Ministry of Education, Youth and Sports of CR within the National Sustainability Program I (NPUI), grant no. LO1415 (funder Id: http://dx.doi. org/10.13039/501100001823).

Employment or leadership: None declared.

Honorarium: None declared. 


\section{References}

Aloui, F., Ayadi, N., Charrier, F., Charrier, B. (2004) Durability of European oak (Quercus petraea and Quercus robur) against white rot fungi (Coriolus versicolor): relations with phenol extractives. Holz. Roh. Werkst. 62:286-290.

Ayadi, N., Charrier, B., Irmouli, M., Charpentier, J.P., Allemand, J.C., Feuillat, F., Keller, R. Interspecific Variability of European Oak Durability against White Rot Fungi (Coriolus versicolor): Comparison between Sessile Oak and Peduncle Oak (Quercus petraea and Quercus robur). IRG/WP/01-10393. The International Research Group on Wood Preservation, Stockholm, 2001.

Baar, J., Paschová, Z., Hofmann, T., Hapla, F. (2017) Effect of site conditions on extractives content in Sessile oak. In IUFRO Division 5 Conference 2017 and $60^{\text {th }}$ SWST International Convention - Forest Sector Innovations for a Greener Future: Final Program, Proceedings and Abstracts. Madison: Society of Wood Science and Technology. Unpaged.

Baldrian, P. (2003) Interactions of heavy metals with white-rot fungi. Enzyme. Microb. Tech. 32:78-91.

Bernát, I. (1983) The distribution of iron in nature. In: Iron Metabolism. Ed. Bernát, I. Springer, Boston. pp. 9-13.

Bhat, T.K., Singh, B., Sharma, O.P. (1998) Microbial degradation of tannins - a current perspective. Biodegradation 9:343-357.

Bednar, H., Fengel, D. (1974) Physikalische, chemische und strukturelle Eigenschaften von regentem und subfossilem Eichenholz. Holz. Roh. Werkst. 32:99-107.

Blanchette, R.A., Nilsson, T., Daniel, G., Abad, A. (1990) Biological degradation of wood. In: Archaeological Wood: Properties, Chemistry, and Preservation. Eds. Rowell, R.M., Barbour, R.J. American Chemical Society, Washington, DC. pp. 141-174.

Brischke, C., Welzbacher, C.R., Rolf-Kiel, H., Augusta, U., Brandt, K., Rapp, A.O. Dauerhaftigkeit von Eichenholz. Holzschutz-Tagung, Göttingen, 2010. pp. 116-136.

Brischke, C., Behnen, C.J., Lenz, M.-T., Brandt, K., Melcher, E. (2012) Durability of oak timber bridges - impact of inherent wood resistance and environmental conditions. Int. Biodeter. Biodegr. 75:115-123.

Budavari, S., Heckelman, P.E., Kinneary, J.F., O’Neil, M.J., Smith, A. The Merck Index: An Encyclopedia of Chemicals, Drugs, and Biologicals. Merck, Whitehouse Station, 1996.

Čufar, K., Gričar, J., Zupančič, M., Koch, G., Schmitt, U. (2008) Anatomy, cell-wall structure and topochemistry of waterlogged archaeological wood aged 5,200 and 4,500 years. IAWA J. 29:55-68.

Charrier, B., Haluk, J.P., Metche, M. (1995) Characterisation of European oak wood constituents acting in the brown discolouration during kiln-drying. Holzforschung 49:168-172.

Dedic, D., Sandberg, T., Iversen, T., Larsson, T., Ek, M. (2014) Analysis of lignin and extractives in the oak wood of the $17^{\text {th }}$ century warship Vasa. Holzforschung 68:419-425.

Doussot, F., de Jéso, B., Quideau, S., Pardon, P. (2002) Extractives content in cooperage oak wood during natural seasoning and toasting; influence of tree species, geographic location, and single-tree effects. J. Agric. Food. Chem. 50:5955-5961.

Esteban, L.G., de Palacios, P., García Fernández, F., García-Amorena, I. (2010) Effects of burial of Quercus spp. wood aged $5910 \pm 250$ $\mathrm{BP}$ on sorption and thermodynamic properties. Int. Biodeter. Biodegr. 64:371-377.
Fengel, D., Wegener, G. Wood - Chemistry, Ultrastructure, Reactions. De Gruyter, Berlin, 1989.

Fergus, B., Goring, D.A.I. (1970) The location of guaiacyl and syringyl lignins in birch xylem tissue. Holzforschung 24:113-117.

Feuillat, F., Dupouey, J.-L., Sciama, D., Keller, R. (1997) A new attempt at discrimination between Quercus petraea and Quercus robur based on wood anatomy. Can. J. For. Res. 27:343-351.

Florian, M.L.E. (1990) Scope and history of archaeological wood. In: Archaeological Wood: Properties, Chemistry and Preservation. Eds. Rowell, R.M., Barbour, R.J. American Chemical Society, Washington, pp. 3-32.

Fojutowski, A., Wróblewska, H., Komorowicz, M., Kropacz, A., Noskowiak, A., Pomian, I. (2014) Changes in the properties of English oak wood (Quercus robur L.) as a result of remaining submerged in Baltic Sea waters for two years. Int. Biodeter. Biodegr. 86:122-128.

Guilley, E., Charpentier, J.P., Ayadi, N., Snakkers, G., Nepveu, G., Charrier, B. (2004) Decay resistance against Coriolus versicolor in Sessile oak (Quercus petraea Liebl.): analysis of the between-tree variability and correlations with extractives, tree growth and other basic wood properties. Wood Sci. Technol. 38:539-554.

Hart, J.H., Hillis, W.E. (1972) Inhibition of wood-rotting fungi by ellagitannins in the heartwood of Quercus alba. Phytopathology 62:620-626.

Haslam, E. (1996) Natural polyphenols (vegetable tannins) as drugs: possible modes of action. J. Nat. Prod. 59:205-215.

Hedges, J.I. (1990) The Chemistry of Archaeological Wood. In: Archaeological Wood: Properties, Chemistry and Preservation. Eds. Rowell, R.M., Barbour, R.J. American Chemical Society, Washington. pp. 111-140.

Herve Du Penhoat, C., Michon, V., Peng, S., Viriot, C., Scalbert, A., Gage, D. (1991) Structural elucidation of new dimeric ellagitannins from Quercus robur L. Roburins A-E. Chem. Soc. Perkin. Trans. 1:1653-1660.

Horský, D., Reinprecht, L. (1986) Štúdia subfosilneho duboveho dreva. VPA 1986/1, VŠLD Zvolen, Zvolen.

Jellison, J., Connolly, J., Goodell, B., Doyle, B., Illman, B., Fekete, F., Ostrofsky, A. (1997) The role of cations in the biodegradation of wood by the brown-rot fungi. Int. Biodeter. Biodegr. 39:165-179.

Karami, L., Fromm, J., Koch, G., Schmidt, O., Schmitt, U. (2014) Oak wood inhabiting fungi and their effect on lignin studied by UV microspectrophotometry. Maderas-Cienc. Tecnol. 16:149-158.

Kleist, G., Schmitt, U. (1999) Evidence of accessory components in vessel walls of Sapelli heartwood (Entandrophragma cylindricum) obtained by transmission electron microscopy. Holz. Roh. Werkst. 57:93-95.

Klumpers, J., Scalbert, A., Janin, G. (1994) Ellagitannins in European oak wood - polymerization during wood ageing. Phytochemistry 36:1249-1252.

Koch, G., Kleist, G. (2001) Application of scanning UV microspectrophotometry to localise lignins and phenolic extractives in plant cell walls. Holzforschung 55:563-567.

Koch, G., Melcher, E., Lenz, M.T., Bauch, J. (2018) Biological and topochemical studies on the resistance of excavated oak piles (Quercus sp.) from a historical bridge in Bavaria. Holzforschung 72:133-141. 
Kolář, T., Rybníček, M. (2011) Dendrochronological and radiocarbon dating of subfossil wood from the Morava River basin. Geochronometria 38:155-161.

Kolář, T., Gryc, V., Rybníček, M., Vavrčík, H. (2012) Anatomical analysis and species identification of subfossil oak wood. Wood Res. 57:251-264.

Kolář, T., Rybníček, M, Střelcová, M., Hedbávný, J, Vít, J. (2014) The changes in chemical composition and properties of subfossil oak deposited in holocene sediments. Wood Res. 59:146-166.

Kollmann, F., Fengel, D. (1965) Änderung der chemischen Zusammensetzung von Holz durch thermische Behandlung. Holz. Roh. Werkst. 23:461-468.

Krisper, P., Tisler, V., Skubic, V., Rupnik, I., Kobal, S. (1992) The use of tannin from chestnut (Castanea vesca). In: Plant Polyphenols. Eds. Hemingway, R.W., Laks, P.E. Plenum Press, New York. pp. 1013-1020.

Krutul, D., Kocoń, J. (1982) Inorganic constituents and scanning electron microscopic study of fossil oak wood (Quercus sp.). Holzforsch. Holzverw. 34:69-77.

Krutul, D., Radomski, A., Zawadzki, J., Zielenkiewicz, T., Antczak, A. (2010) Comparison of the chemical composition of the fossil and recent oak wood. Wood Res. 55:113-120.

Lei, Z. Monomeric Ellagitannins in Oaks and Sweetgum, PhD thesis. Virginia Polytechnic Institute and State University, Virginia, 2002. p. 145.

Lewis, R.J. Hawley's Condensed Chemical Dictionary. Van Nostrand Reinhold Co., New York, 1993.

Lyr, H. (1962) Detoxification of heartwood toxins and chlorophenols by higher fungi. Nature 4836:289-290.

Maas, J.L., Galletta, G.J., Stoner, G.D. (1991) Ellagic acid, an anticarcinogen in fruits, especially in strawberries. A review. Hort. Sci. 26:10-14.

Mańkowski, P., Kozakiewicz, P., Zielenkiewicz, T. (2013) Investigations of iron content in fossil oak from a medieval settlement in Płońsk. Ann WULS - SGGW Forest. Wood Technol. 83:201-205.

Masson, G., Moutounet, M., Puech, J.L. (1995) Ellagitannin content of oak wood as a function of species and of sampling position in the tree. Am. J. Enol. Viticult. 46:262-268.

Meyer, L., Brischke, C., Melcher, E., Brandt, K., Lenz, M.T., Soetbeer, A. (2014) Durability of English oak (Quercus robur L.) - comparison of decay progress and resistance under various laboratory and field conditions. Int. Biodeter. Biodegr. 86:79-85.

Mila, I., Scalbert, A., Expert, D. (1996) Iron withholding by plant polyphenols and resistance to pathogens and rots. Phytochemistry 42:1551-1555.

Mosedale, J.R., Charrier, B., Janin, G. (1996) Genetic control of wood colour, density and heartwood ellagitannin concentration in European oak (Quercus petraea and Q. robur). Forestry 69:111-124.

Mosedale, J., Feuillat, F., Baumes, R., Dupouey, J.L., Puech, J.L. (1998) Variability of wood extractives among Quercus robur and Quercus petraea trees from mixed stands and their relation to wood anatomy and leaf morphology. Can. J. Forest. Res. 28:1-13.

Musha, Y., Goring, D.A.I. (1975) Distribution of syringyl and guaiacyl moieties in hardwoods as indicated by ultraviolet microscopy. Wood. Sci. Technol. 9:45-58.

Passialis, C.N. (1997) Physico-chemical characteristics of waterlogged archaeological wood. Holzforschung 51:111-113.

Prida, A., Boulet, J.C., Ducousso, A. (2006) Effect of species and ecological conditions on ellagitannin content in oak wood from an even-aged and mixed stand of Quercus robur L. and Quercus petraea Liebl. Ann. For. Sci. 63:415-524.
Peng, S., Scalbert, A., Monties, B. (1991) Insoluble ellagitannins in Castanea sativa and Quercus petraea woods. Phytochemistry 30:375-378.

Scalbert, A. (1992) Tannins in woods and their contribution to microbial decay prevention. In: Plant Polyphenols. Eds. Hemingway, R.W., Laks, P.E. Plenum Press, New York. pp. 935-952.

Scalbert, A., Monties, B., Favre, J.M. (1988) Polyphenols of Quercus robur: adult tree and in vitro grown calli and shoots. Phytochemistry 27:3483-3488.

Seikel, M.K., Hostettler, E.D., Niemann, G.J. (1971) Phenolics of Quercus robur wood. Phytochemistry 10:2249-2251.

Solár, R., Reinprecht, L., Kačík, F., Melcer, I., Horský, D. (1987) Comparison of some physico-chemical and chemical properties of polysacharidic and lignin part of contemporary and subfossil oak wood. Cell. Chem. Technol. 2:513-524.

Spurr, A.R. (1969) A low-viscosity epoxy resin embedding medium for electron microscopy. J. Ultrastruct. Res. 26:31-43.

Swain, T., Bate-Smith, E.C. (1962) Flavanoid compounds. In: Comparative Biochemistry. Eds. Florkin, M., Mason, H.S. Academic Press, New York. pp. 755-809.

Szczepkowski, A. (2010) Odporność drewna dębu szypułkowego (Quercus robur L.), z drzew o różnym stanie zdrowotnym, na rozkład powodowany przez grzyby. Leśne prace badawcze 71:125-133.

Thaler, N., Humar, M. (2013) Changes of fungicidal, mechanical and sorption properties of wood during above ground outdoor exposure. Proceedings IRG Annual Meeting. IRG/WP: 13-20513.

Viriot, C., Scalbert, A., Hervé du Penhoat, C.L.M., Moutounet, M. (1994) Ellagitannins in woods of sessile oak and sweet chestnut dimerization and hydrolysis during wood ageing. Phytochemistry 36:1253-1260.

Vít, J., Kolář, T., Rybníček, M. (2009) Předběžné výsledky studia vztahu subfosilních kmenů a fluviálních sedimentů na lokalitách Osek nad Bečvou a Tovačov-Annín (Preliminary results of the relationship between subfossil trunks and fluvial sediments in the areas of Osek nad Bečvou and Tovačov-Annín). Geologické výzkumy na Moravě a ve Slezsku 1:53-55.

Vivas, N., Glories, Y., Bourgeois, G., Vitry, C. (1996) The heartwood ellagitannins of different oak (Quercus sp.) and chestnut species (Castanea sativa Mill.). Quantity analysis of red wines aging in barrels. Journal des Sciences et Techniques de la Tonnelerie 2:25-75.

Wagenführ, R. Holzatlas. Fachbuchverlag Leipzig im Carl Hanser Verlag, München, 2000.

Wakeling, R., Morris, P. (2014) Wood deterioration: ground contact hazards. In: Deterioration and Protection of Sustainable Biomaterials. Eds. Schultz, T., Goodell, B., Nicholas, D.D. American Chemical Society, Washington. pp. 131-146.

Welling, J., Schwarz, T., Bauch, J. (2018) Biological, chemical and technological characteristics of waterlogged archaeological piles (Quercus petraea (Matt.) Liebl.) of a medieval bridge foundation in Bavaria. Eur. J. Wood Wood Prod. 76:1173-1186.

Williams, A.H. (1963) Enzyme inhibition by phenolic compounds. In: Enzyme Chemistry of Phenolic Compounds. Ed. Pridham, J.B. Pergamon Press, New York.

Williams, D.J., Edwards, D., Chaliha, M., Sultanbawa, Y. (2016) Measuring free ellagic acid: influence of extraction conditions on recovery by studying solubility and UV-Visible spectra. Chem. Pap. 70:1078-1086.

Zhang, B., Cai, J., Duan, C.Q., Reeves, M.J., He, F. (2015) A review of polyphenolics in oak woods. Int. J. Mol. Sci. 16:6978-7014. 